\title{
Method of Estimating the Carbon Footprint of Wastewater Treatment Plants ${ }^{\dagger}$
}

\author{
Ewa Szatyłowicz*(D), Iwona Skoczko (D) and Paweł Puzowski
}

Citation: Szatyłowicz, E.; Skoczko, I.; Puzowski, P. Method of Estimating the Carbon Footprint of Wastewater Treatment Plants. Environ. Sci. Proc. 2021, 9, 30. https://doi.org/10.3390/ environsciproc 2021009030

Academic Editors: Dorota Anna Krawczyk and Antonio Rodero Serrano

Published: 11 November 2021

Publisher's Note: MDPI stays neutral with regard to jurisdictional claims in published maps and institutional affiliations.

Copyright: (c) 2021 by the authors Licensee MDPI, Basel, Switzerland. This article is an open access article distributed under the terms and conditions of the Creative Commons Attribution (CC BY) license (https:/ / creativecommons.org/licenses/by/ $4.0 /)$.
Department of Technology in Environmental Engineering, Faculty of Civil and Environmental Science, Bialystok University of Technology, Wiejska 45A, 15-351 Bialystok, Poland; i.skoczko@pb.edu.pl (I.S.); p.puzowski@doktoranci.pb.edu.pl (P.P.)

* Correspondence: e.szatylowicz@pb.edu.pl

† Presented at the Innovations-Sustainability-Modernity-Openness Conference (ISMO'21), Bialystok, Poland, 14 May 2021.

\begin{abstract}
Wastewater treatment operations focus on removing pollutants from wastewater to meet water quality standards for public health and environmental protection. However, in recent decades new sustainability targets for wastewater treatment plants have been postulated and implemented, which assume that energy is one of the key elements. Therefore, a transition from a negative energy balance (energy demand covered by external sources) to an energy-neutral or unevenly positive energy balance of wastewater treatment has been postulated. The carbon footprint (CF) is a new measure of sustainability in the wastewater sector for determining the overall impact of wastewater treatment plants on climate change. The following paper presents a method for estimating and assessing the carbon footprint of wastewater treatment plants.
\end{abstract}

Keywords: carbon footprint; wastewater treatment plant; GHG

\section{Introduction}

Wastewater treatment plants are one of the most expensive sectors in terms of energy requirements in the European Union. It consumes a large amount of energy to treat wastewater for its reuse or disposal in the environment. According to the International Energy Agency, global energy consumption for wastewater storage and treatment will consume more than $60 \%$ of the energy consumed in 2014 . The amount of wastewater that needs to be treated is increasing, linked to ongoing economic development [1].

Wastewater treatment plants (WWTPs) are a source of anthropogenic greenhouse gas (GHG) emissions to the atmosphere that contribute to climate change [2-5]. GHGs are emitted directly as methane $\left(\mathrm{CH}_{4}\right)$ and nitrous oxide $\left(\mathrm{N}_{2} \mathrm{O}\right)$ or indirectly as carbon dioxide $\left(\mathrm{CO}_{2}\right)$ of fossil origin (due to energy and materials used in treatment processes) [6]. Unorganised $\mathrm{CO}_{2}$ emissions from wastewater treatment plants are not included directly in the reporting of GHG emissions. They are considered to be emissions of biogenic origin and therefore belong to the short carbon cycle [7]. The overall contribution of wastewater treatment plants to climate change is obtained by assessment of the plant's carbon footprint. In recent years, there has been an increased interest in energy balance reduction and increasing the efficiency of wastewater treatment plants. Consequently, attention has been given to CF minimisation [8-10]. All relevant forms of energy demand such as electricity, heat, chemicals, fossil fuels, transport), and GHG emissions-carbon dioxide $\left(\mathrm{CO}_{2}\right)$, methane $\left(\mathrm{CH}_{4}\right)$, and nitrous oxide $\left(\mathrm{N}_{2} \mathrm{O}\right)$ are commonly included in $\mathrm{CF}$ assessment. These GHGs are among the six GHGs to be reduced under the Kyoto Protocol and reported in the GHG inventory [7]. 


\section{Carbon Footprint Objectives of a Wastewater Treatment Plant}

The carbon footprint assessment is useful at two different stages of the $\mathrm{CF}$ reduction implementation [4]:

- In the initial phase, when it is necessary to choose a strategy to reduce GHG emissions, as it indicates the factors that cause the greatest environmental impact;

- In the final phase, the carbon footprint verifies the success of the measures taken to change the energy balance.

Furthermore, the determination of the carbon footprint allows the stakeholders of wastewater treatment plants to understand how much these facilities contribute to the global emission of anthropogenic greenhouse gases. At the European level, the European Environment Agency promotes the assessment of the carbon footprint of water and wastewater management facilities from a life cycle perspective [4].

\section{Method of Estimating the Carbon Footprint}

The carbon footprint is most accurately calculated using life cycle assessment or inputoutput analysis [10-12]. In this sense, it is based on the ISO 14040 [12] and ISO 14043 [13] standards for life cycle assessment (LCA). Specific standards for the carbon footprint of companies and products are ISO 14064 (parts 1, 2, and 3) [14,15], ISO 14067 [16], and PAS 2500 [17]. The process of the carbon footprint calculation is shown in Figure 1.

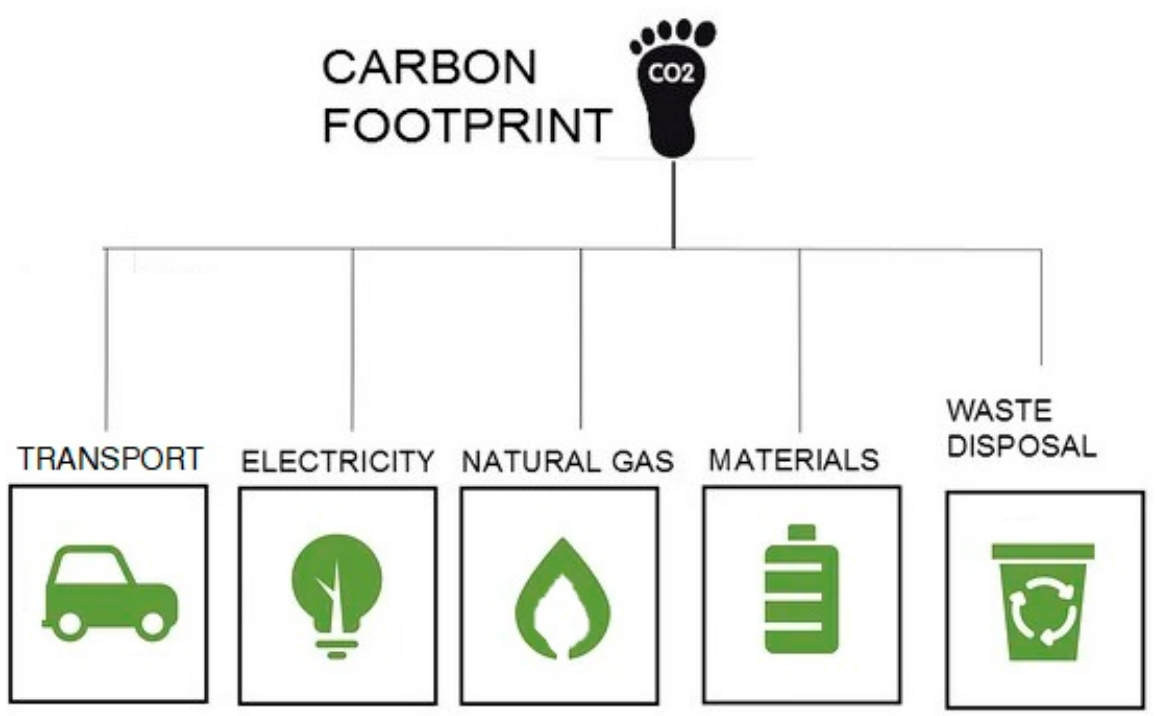

Figure 1. Calculation scheme CF.

The general methodology for estimating the carbon footprint for the operations of industrial production companies is based on the ISO 14067:2013 standard [16]. The CF calculation methodology considered in this standard is based on the calculation of CF over the entire life cycle of a company and divides the necessary inventory data into two general categories [16,18]:

- Direct emissions and removals of GHGs-covering emissions occurring within the company and determined by monitoring (stoichiometry or mass balance). Direct emissions are those controlled by the organisation, but can also be interpreted as having no prior or subsequent technological history,

- Activity data-covering inputs and outputs of materials entering and leaving the organisation, which have their technological history resulting in GHGs emissions, e.g., transport of fuels $[18,19]$ :

With this classification, ISO 14067:2013 [16] groups GHGs emissions into three scopes:

- $\quad$ Scope 1-GHGs emissions from sources owned or controlled by the organisation (direct emissions); 
- Scope 2-GHGs emissions from the production of electricity, heat or steam consumed by the organisation (indirect energy GHGs emissions);

- $\quad$ Scope 3-GHGs emissions other than indirect energy GHGs emissions that result from the organisation's activities, but are generated at sites owned or supervised by other organisations.

To perform this analysis, the literature data can be used for each product consumed, as well as transport volumes within the entire supply chain, or the product and process LCA indicator databases available in the literature or included in commercial (Ecoinvent) or free databases (JRC Ispra) [18].

\section{Conclusions}

Carbon footprint calculation makes it possible to control the energy balance of companies and products, including water and wastewater facilities. It also helps to prevent phenomena such as global warming, environmental change, reduced potable water supplies, and forest loss. It may have also an important impact on business management.

Author Contributions: Conceptualization, E.S. and I.S.; methodology, I.S.; formal analysis, E.S.; investigation, I.S.; resources, P.P.; data curation, P.P.; writing-original draft preparation, E.S. and I.S.; writing-review and editing, E.S., I.S. and P.P.; visualization, E.S.; supervision, I.S.; project administration, I.S. All authors have read and agreed to the published version of the manuscript.

Funding: This research was funded by Polish Ministry of Higher Education and Science grant number WI/WB-IIŚ/21/2019.

Institutional Review Board Statement: Not applicable.

Informed Consent Statement: Not applicable.

Data Availability Statement: Not applicable.

Conflicts of Interest: The authors declare no conflict of interest.

\section{References}

1. Slaboch, J.; Hálová, P.; Laputková, A. Development and Structural Changes of Carbon Footprint in EU28. Sustainability 2021, 13, 4771. [CrossRef]

2. Maktabifard, M.; Zaborowska, E.; Makinia, J. Energy neutrality versus carbon footprint minimization in municipal wastewater treatment plants. Bioresour. Technol. 2020, 300, 122647. [CrossRef] [PubMed]

3. Delre, A.; ten Hoeve, M.; Scheutz, C. Site-specific carbon footprints of Scandinavian wastewater treatment plants, using the life cycle assessment approach. J. Clean. Prod. 2019, 211, 1001-1014. [CrossRef]

4. EEA. Performance of Water Utilities beyond Compliance-Sharing Knowledge Bases to Support Environmental and Resource-Efficiency Policies and Technical Improvements; Jacobsen, B.N., Ed.; Publications Office of the European Union: Copenagen, Denmark, 2014. [CrossRef]

5. IPCC. Climate $€$ Change 2014: Mitigation of Climate Change. In Contribution of Working Group III to the Fifth Assessment Report of the Intergovernmental Panel on Climate Change; Edenhofer, O., Pichs-Madruga, R., Sokona, Y., Farahani, E., Kadner, S., Seyboth, K., Adler, A., Baum, I., Brunner, S., Eickemeier, P., et al., Eds.; Cambridge University Press: New York, NY, USA, 2014.

6. IPCC. IPCC Guidelines for National Greenhouse Gas Inventories Prepared by the National Greenhouse Gas Inventories Programme; Institute for Global Environmental Strategies: Kanagawa, Japan, 2006; Volume 5.

7. Yoshida, H.; Clavreul, J.; Scheutz, C.; Christensen, T.H. Influence of data collection schemes on the Life Cycle Assessment of a municipal wastewater treatment plant. Water Res. 2014, 56, 292-303. [CrossRef] [PubMed]

8. Xu, J.; Li, Y.; Wang, H.; Wu, J.; Wang, X.; Li, F. Exploring the feasibility of energy self-sufficient wastewater treatment plants: A case study in eastern China. Energy Procedia 2017, 142, 3055-3061. [CrossRef]

9. Ødegaard, H. A road-map for energy-neutral wastewater treatment plants of the future based on compact technologies (including MBBR). Front. Environ. Sci. Eng. 2016, 10, 2. [CrossRef]

10. Hertwich, E.; Peters, G. Carbon footprint of nations: A global, trade-linked analysis. Environ. Sci. Technol. 2009, 43, 6414-6420. [CrossRef] [PubMed]

11. ISO. ISO 14040: Environmental Management_Life Cycle Assessment_Principles and Framework; International Organization for Standardization: Geneva, Switzerland, 2006.

12. ISO. ISO 14044: Environmental Management_Life Cycle Assessment_Requirement sand Guidelines; International Organization for Standardization: Geneva, Switzerland, 2006. 
13. ISO. ISO 14064-1: Greenhouse Gases-Part 1: Specification with Guidance at the Organization Level for Quantification and Reporting of Greenhouse Gas Emissions and Removals; International Organization for Standardization: Geneva, Switzerland, 2006.

14. ISO. ISO 14064-2: Greenhouse Gases-Part 2: Specification with Guidance at the Project Level for Quantification, Monitoring and Reporting of Greenhouse Gas Emission Reductions or Removal Enhancements; International Organization for Standardization: Geneva, Switzerland, 2006.

15. ISO. ISO 14064-3: Greenhouse Gases_Part 3: Specification with Guidance for the Validation and Verification of Greenhouse Gas Assertions; International Organization for Standardization: Geneva, Switzerland, 2006.

16. ISO. ISO/TS 14067: Greenhouse Gases e Carbon Footprint of Products e Requirements and Guidelines for Quantification and Communication; International Organization for Standardization: Geneva, Switzerland, 2013.

17. BSI. PAS 2050:2011 Specification for the Assessment of the Life Cycle Greenhouse Gas Emissions of Goods and Services; British Standards Institution: London, UK, 2011.

18. Kulczycka, J.; Wernicka, M. Methods and results of calculating the carbon footprint of the activity of selected entities in the energy and mining sectors. Sci. J. Inst. Miner. Energy Econ. Pol. Acad. Sci. 2015, 89, 133-141. (In Polish)

19. Bałazińska, M.; Zuwała, J.; Tokarski, S. Carbon footprint related to the transport of fuels for energy purposes. Energy Mark. 2013, 4, 68-73. (In Polish) 